\title{
Assessing the potential of Yersinia entomophaga to control plantain moth in a laboratory assay
}

\author{
S.A. Jones ${ }^{1}$, C.M. Ferguson ${ }^{2}$, B.A. Philip ${ }^{2}$, C. van Koten ${ }^{1}$ and M.R.H. Hurst ${ }^{1}$ \\ ${ }^{1}$ AgResearch Lincoln, Private Bag 4749, Christchurch 8140, New Zealand \\ ${ }^{2}$ AgResearch Invermay Agricultural Centre, Puddle Alley, Private Bag 50034 \\ Mosgiel 9053, New Zealand \\ Corresponding author: mark.hurst@agresearch.co.nz
}

\begin{abstract}
The recent increased use of the high-quality drought-tolerant forage plant plantain (Plantago lanceolata) (Plantaginaceae) has been associated with outbreaks of native geometrid caterpillars, such as Scopula rubraria. The outbreaks most often occur under warm climatic conditions and within plantain monocrops. Pest populations can reach 11,500 larvae $/ \mathrm{m}^{2}$. Stands can be severely damaged with $90 \%$ of plants destroyed and stand life expectancy reduced by 2-3 years. This study assessed the efficacy of the insecticidal bacterium Yersinia entomophaga against $S$. rubraria under laboratory conditions using a leaf dip bioassay. A $\mathrm{LD}_{50}$ of $2.26 \pm 0.33 \times 10^{5}$ cells per larva was determined with an $\mathrm{LT}_{50}$ defined as 3.1 days when treated with $4.8 \times 10^{6}$ cells per larva. These data combined with the life history of S. rubraria and the pathobiology of Y. entomophaga suggest the bacterium could be developed as a biopesticide for use against $S$. rubraria.
\end{abstract}

Keywords plantain, Plantago lanceolata, plantain moth, Scopula rubraria, Yersinia entomophaga, biopesticide, control agent.

\section{INTRODUCTION}

In recent years, the forage plant plantain (Plantago lanceolata; Plantaginaceae) has been sown by increasing numbers of farmers who perceive advantage can be gained from the plant's drought tolerance and high feed quality that provides high stock live weight gains. Plantain is now commonly grown in both the North and South Islands, typically planted as a plantain/clover mix (Stewart et al. 2014) but also as a monoculture forage crop or as a component of mixed pastures. In the North Island native looper caterpillars, now commonly referred to as plantain moth caterpillars, have emerged as significant pests due to their voracious feeding and ability to rapidly reach very high population densities as a consequence being able to complete several generations per year (Ferguson \& Philip 2014).

"Plantain moths" belong to the family Geometridae, and the group comprises at least two species, Scopula rubraria (Doubleday) and Epyaxa rosearia (Doubleday), which are widespread and common in both islands. To a layperson these species appear very similar. Both are thought to be New Zealand native species, with $S$. rubraria also present in Australia (Philip \& Ferguson 2014). Other closely related species in both genera may also form part of this complex. Neither of the recognised species has been extensively studied within an agricultural context but one study has shown that $S$. rubraria 
can reach numbers as high as 11,500 larvae $/ \mathrm{m}^{2}$ in plantain stands, at times consuming up to $90 \%$ of the crop (Ferguson \& Philip 2014). This damage typically occurs in areas where plantain is sown as a monoculture, or in conjunction with clover, and under dry summer conditions that favour S. rubraria growth and multiplication. Both S. rubraria (Philip \& Ferguson 2014) and E. rosearia (P.J. Gerard, AgResearch, personal communication) appear to have several generations per year, with the number of generations determined by spring and summer temperatures. Consequently both species can become very abundant by late summer but populations decline towards late autumn. Anecdotal evidence suggests that first year crops are relatively untouched by pests but those in the second or third year can be badly hit particularly when adverse drought conditions place stress on plantain slowing its growth. Within pastoral systems, S. rubraria damage appears to be confined to plantain, but E. rosearia has previously been recorded damaging Caucasian clover (Trifolium ambiguum) and white clover (T. repens) (Watson et al. 1996a,b).

There are currently no insecticides registered specifically for control of plantain moth caterpillars but insecticides effective against a range of other lepidopteran pests may also provide control of plantain moths. Stock withholding periods associated with insecticide applications may, however, be incompatible with grazing.

The non spore-forming bacterium Yersinia entomophaga (Enterobacteriaceae) originally isolated from the cadaver of a Costelytra zealandica (Coleoptera: Scarabaeidae) larva, has been shown to be pathogenic by per os challenge to a wide range of lepidopteran, coleopteran and orthopteran species (Hurst et al. 2011a). Field efficacy of $Y$. entomophaga has also been demonstrated against larvae of the pasture pest porina (Wiseana spp. Lepidoptera: Hepialidae) (Ferguson et al. 2012) and adult bronze beetles (Eucolaspis sp., Coleoptera: Chrysomelidae) in caged field trials in apple orchards (Hurst et al. 2011b).

This study aimed to demonstrate efficacy of $Y$. entomophaga against larvae of S. rubraria, one of the plantain moths. Dose response assays were carried out on laboratory-reared larvae as a prerequisite to determining the potential of $Y$. entomophaga as an efficacious biopesticide of plantain moths.

\section{MATERIALS AND METHODS Insects}

Scopula rubraria adults and larvae were fieldcollected from a mixed plantain/grass sward at Halcombe, Manawatu, in February 2014. Theidentityof thesewassubsequently confirmed by Brian Patrick, Wildland Consultants, Christchurch (Ferguson \& Philip 2014). These individuals were used to start a laboratory colony. Adults were kept in $180 \times 160 \times 70 \mathrm{~mm}$ clear acrylic containers with mesh lids during mating and oviposition. Plantain foliage and paper towels were provided as substrates for egg-laying and cotton wool dental wicks moistened with a $10 \%$ honey/water solution were supplied as food. Larvae were mass-reared in containers described above and were fed plantain leaves on a layer of paper towels. Leaf material and paper towels were replaced as necessary. Pupae were removed to $60 \mathrm{ml}$ specimen containers for moth emergence. All rearing stages were kept at $17 \pm 1^{\circ} \mathrm{C}$ and $16: 8 \mathrm{~h}$ light:dark. Fourth instar and early $5^{\text {th }}$ instar larvae (5-10 $\mathrm{mm}$ length) from the $3^{\text {rd }}$ laboratory generation of caterpillars were used in the experiment.

\section{Bioassay}

Yersinia entomophaga was grown in LuriaBertani (LB) broth at $25^{\circ} \mathrm{C}$ for $18 \mathrm{~h}$ as described previously (Hurst et al. 2014). For assessment in the bioassay, five rates of $Y$. entomophaga cells were prepared by performing ten-fold serial dilutions to give doses ranging between $5 \times 10^{3}$ and $5 \times 10^{7} \mathrm{cfu} /$ dose. Dilutions were made in water with the addition of $0.04 \%$ DuWett (Elliot Chemicals Ltd), which assisted in application of the bacterial suspension to the plantain leaf discs in the bioassay.

Immediately prior to the assay, $2.5 \mathrm{~cm}$ leaf discs were excised from freshly cut plantain leaves, collected from plants that had been maintained in pots in the glasshouse. The leaf discs were dipped into dilutions of the culture described above, and were air dried for $1 \mathrm{~h}$ at ambient room temperature. Individual discs were then placed on a piece of Whatman ${ }^{\circledR}$ filter paper (grade no. 5) 
located at the base of a $70 \mathrm{ml}$ specimen screw cap container and five fourth instar S. rubraria larvae were added to each container. The five replicate containers per treatment, including a $0.04 \%$ DuWett in water only control, were arranged in a randomised block design within a covered plastic container kept at $18^{\circ} \mathrm{C}$. The larvae were observed daily over 6 days for mortality. Feeding activity was determined by visually assessing the percentage of leaf disc that had been eaten. On day 3 of the assay any uneaten leaf was removed from the containers and replaced with a fresh uninoculated leaf disc. This was to prevent larval mortality due to lack of food and cannibalism.

To validate that $Y$. entomophaga was the causative agent of larval mortality, $48 \mathrm{~h}$ after commencement of the assay, two dead larvae from each treatment were randomly selected. The cadavers were surface sterilised by submerging in $30 \mathrm{ml}$ of $70 \%$ ethanol for $60 \mathrm{~s}$, washed in sterile distilled water and surface moisture removed with tissue paper. The individual larvae were homogenised in $1.5 \mathrm{ml}$ of sterile $0.1 \mathrm{M}$ phosphate buffer ( $\mathrm{pH}$ 7.4) in a micro-centrifuge tube. The homogenates were streaked onto LB agar plates and Y. entomophaga colonies confirmed by patching 10 random colonies onto Orientation ChromAgar (Fort Richard Laboratories, Auckland, New Zealand) and incubating for $24 \mathrm{~h}$ at $25^{\circ} \mathrm{C}$. Yersinia entomophaga colonies appear purple following incubation.

\section{Statistical methods}

Minitab version 16 was used to assess larval mortality and feeding activity data to calculate means and standard errors. For the live $Y$. entomophaga treatment groups, $\mathrm{LD}_{50}$ on day 6 was estimated using probit analysis. The dose level of Y. entomophaga live cells of each treatment group was calculated per caterpillar, by multiplying the applied cell count per leaf disc by average percentage of the disc consumed until day 3 across five replicates, then, dividing by five caterpillars. The time to achieve 50\% mortality $\left(\mathrm{LT}_{50}\right)$ value for each treatment group was estimated in parametric survival (or timeto-event) analysis. In the analysis, standard statistical curved functions were fitted to cumulative mortalities of the group during the 6-day post treatment period and the function that most closely reflected mortality was chosen to estimate the $\mathrm{LT}_{50}$ value.

\section{RESULTS}

Yersinia entomophaga cells applied at the two highest rates of $4.8 \times 10^{7}$ cells and $4.8 \times 10^{6}$ cells /leaf disc caused $100 \%$ mortality of S. rubraria larvae within 6 days and there was a highly significant effect $(\mathrm{P}<0.001)$ on larval mortality on day 6 where an application rate of $4.8 \times 10^{5}$ cells/leaf disc was used (Figure 1a) in comparison to the untreated control. Mortality levels $(<15 \%)$ at lower concentrations were not significantly different to the control group mortality of $10 \%$.

Yersinia entomophaga live cells applied at the highest rate had a highly significant effect on amount of leaf material consumed by day 3 , with approximately $8 \%$ of leaf material consumed by larvae in comparison with $89 \%$ consumption in the control (Figure 1b). Larvae in the highest dose treatment began feeding but had consumed less than $10 \%$ of the leaf disc before dying. There was no significant reduction in feeding at lower dose rates compared to the control group by day 3, and larvae in these groups continued to feed when provided with a fresh uninoculated leaf disc. At day 6 the reduced levels of leaf consumed in the $4.8 \times 10^{7}, 4.8 \times 10^{6}$ and $4.8 \times 10^{5}$ treatments most likely reflected the high level of larval mortality $(>62 \%)$ in those groups.

Through probit analysis the predicted $\mathrm{LD}_{50}$ of $Y$. entomophaga cells per S. rubraria larva was estimated to be $2.26 \pm 0.33 \times 10^{5}$ (Mean \pm SEM) (Figure 2).

The time taken for larvae to die was proportional to the dose rate of $Y$. entomophaga. Rapid death $\left(\mathrm{LT}_{50} 2.5 \pm 0.1\right.$ days) (Mean \pm SEM) occurred at the highest rate $\left(4.8 \times 10^{7} /\right.$ leaf disc) but was much slower ( $\mathrm{LT}_{50} 4.9 \pm 0.3$ days) (Mean \pm SEM) with 100-fold less cells $\left(4.8 \times 10^{5}\right.$ / leaf disc) (Figure 3).

Yersinia entomophaga was detected in all cadavers sampled at $48 \mathrm{~h}$, with numbers of Y. entomophaga varying between $1 \times 10^{3}$ and $5 \times 10^{4}$ cells per larvae (total of 4 cadavers assessed). 

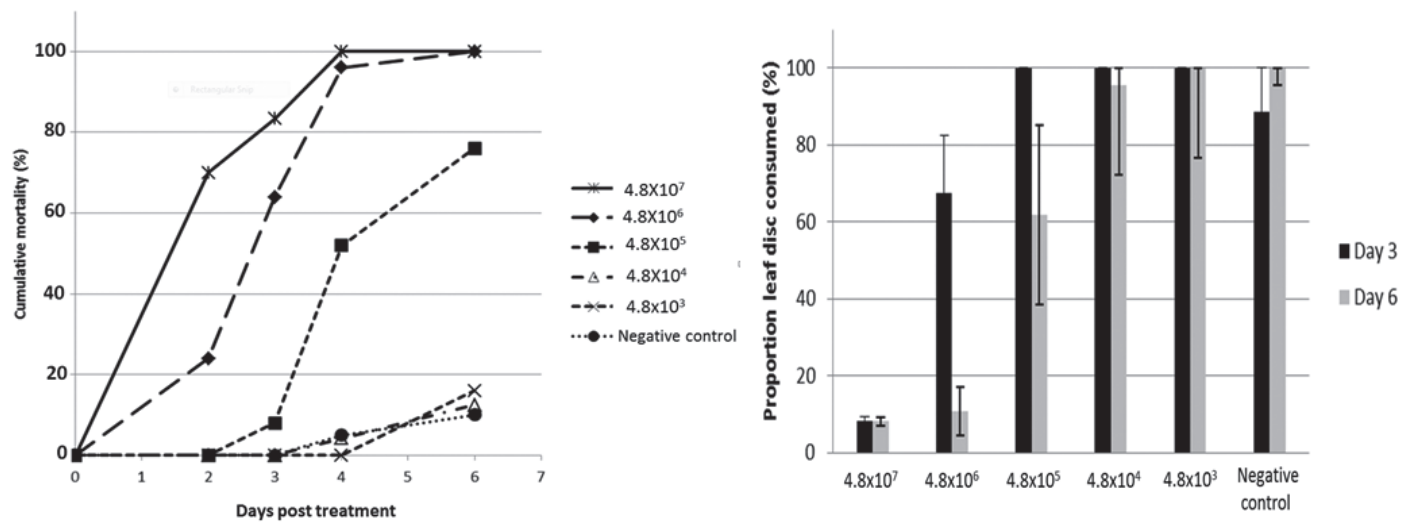

Figure 1 (a) Mortality (\%) of Scopula rubraria larvae after treatment with different concentrations of Yersinia entomophaga live cells/leaf disc over time. (b) Mean proportion (\%) of treated leaf disc consumed by day 3 , and fresh leaf disc consumed from day 3 until day 6 of the bioassay period. Error bars denote the $95 \%$ confidence intervals

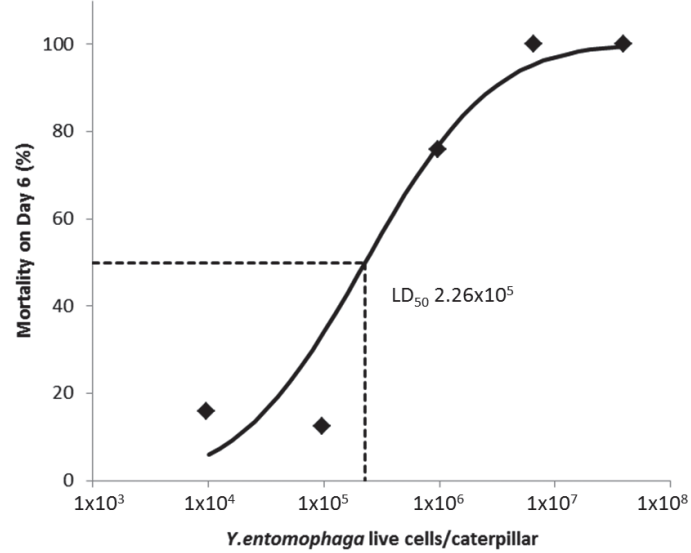

Figure 2 Fitted relationship using the probit model between log dose of Yersinia entomophaga and mortality of Scopula rubraria after 6 days showing $\mathrm{LD}_{50}$ of $2.26 \times 10^{5}$ cells/larva.

\section{DISCUSSION}

The results of this laboratory study have shown that Y. entomophaga caused rapid death of 4th instar S. rubraria larvae, with an $\mathrm{LD}_{50}$ of 2.26 $\pm 0.33 \times 10^{5} \mathrm{Y}$. entomophaga cells/larva. At a leaf dip rate of greater than $4.8 \times 10^{7}$ cells/leaf disc, $100 \%$ mortality was observed within 6 days, while at a leaf dip rate of $4.8 \times 10^{5}$ cells/leaf disc, a $\mathrm{LT}_{50}$ of approximately 5 days was defined.

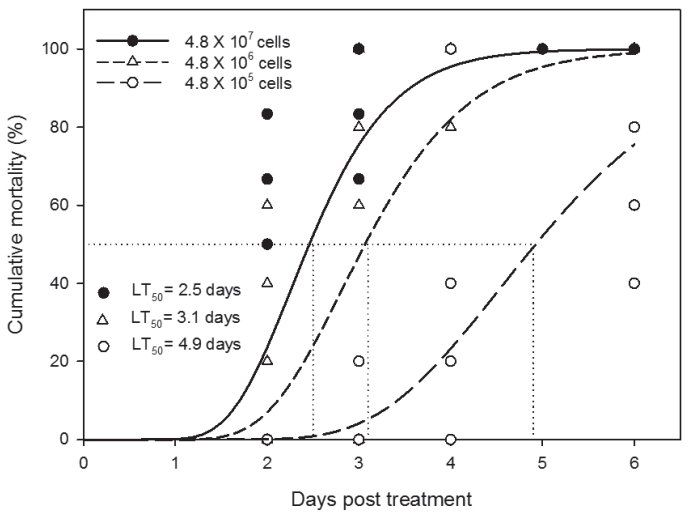

Figure 3 Mean cumulative mortality curves estimated from the best-fit survival functions derived from the observed mortality of Scopula rubraria larvae after treatment with Yersinia entomophaga at $4.8 \times 10^{7}$ cells, $4.8 \times 10^{6}$ cells or $4.8 \times 10^{5}$ cells/leaf disc.

These bacterial foliar concentrations are within the range of cell concentrations typically found after foliar application of $Y$. entomophaga. For example, approximately $5 \times 10^{5}-5 \times 10^{6} \mathrm{cells} / \mathrm{cm}^{2}$ were recovered from apple leaf surfaces or grass following field application (Hurst et al. 2011b; Ferguson et al. 2012).

Yersinia entomophaga survives for a relatively short time on foliage with no significant field- 
based foliar persistence of the bacterium from 3 days post spray application (Hurst et al. 2011b; Ferguson et al. 2012). As a non spore-forming bacterium it is sensitive to environmental stresses such as desiccation and exposure to UV light. To be effective in control of plantain moths, it must achieve rapid knockdown of these pests and the laboratory tests reported here suggest this can be achieved. In the field, plantain moth larvae can reach densities in excess of 11,500 larvae $/ \mathrm{m}^{2}$ (Philip \& Ferguson 2014). These high densities, combined with the voracious appetite of plantain moth larvae, make them an ideal target for a $Y$. entomophaga-based foliar application. Further to this, the population build-up of Y. entomophaga in the plantain larvae cadavers, coupled with observed cannibalistic habits of the pest may assist in spread of infection and prolong persistence of Y. entomophaga in the field.

The limited foliar persistence combined with the speed of kill means that the bacterium $Y$. entomophaga should be applied using a strategy similar to that of an insecticide, where the bacterium is sprayed to rapidly knock down an infestation. Due to the multiple generations of plantain moth that can occur within a season, an early application in December should prevent the build-up of caterpillar numbers in late summer leading to less pressure for autumn pastures.

In future studies, the ability of Y. entomophaga to kill other plantain pests, e.g. Epyaxa rosearia and leafroller caterpillars (Family Tortricidae), Merophyas leucaniana (New Zealand native) and M. divulsana (Australian species), will also be determined. Improved foliar sprays and other delivery techniques for Y. entomophaga are also being investigated in the MBIE funded programme, Next Generation Biopesticides and will benefit efficacy testing in future field trials targeting plantain pests.

\section{ACKNOWLEDGEMENTS}

This study was supported by the Ministry of Business, Innovation and Employment, New Zealand (Next Generation Biopesticides; C10X1310).

\section{REFERENCES}

Ferguson CM, Barton DM, Harper LA, Swaminathan J, van Koten C and Hurst MRH 2012. Survival of Yersinia entomophaga MH96 in a pasture ecosystem and effects on pest and nontarget invertebrate populations. New Zealand Plant Protection 65: 166-173

Ferguson CM, Philip BA 2014. Plantain moth investigation. Report for Beef+Lamb New Zealand (A20551), AgResearch Client Report Number: RE400/2014/548. http://beeflambnz. com/Documents/Farm/Plantain\%20moth\%20 investigation.pdf (accessed 15 June 2015). 13 p.

Hurst MRH, Becher SA, Young SD, Nelson TL, Glare TR (2011a). Yersinia entomophaga sp. nov., isolated from the New Zealand grass grub Costelytra zealandica. International Journal of Systematic and Evolutionary Microbiology 61: 844-849.

Hurst MRH, Rogers DJ, Wright DA, Townsend RJ, Bruening R, Cole LM, Harper LA, Jackson TA 2011b. Effect of the bacterium Yersinia entomophaga on adult bronze beetle. New Zealand Plant Protection 64: 209-214.

Hurst MRH, van Koten C, Jackson TA 2014. Pathology of Yersinia entomophaga MH96 towards Costelytra zealandica (Coleoptra: Scarabaeidae) larvae. Journal of Invertebrate Pathology 115: 102-107.

Philip BA, Ferguson CM 2014. Larval development of the plantain feeding moth Scopula rubraria (Doubleday) (Lepidoptera: Geometridae). New Zealand Plant Protection 67: 327 (Abstract only).

Stewart A 1996. Plantain (Plantago lanceolata)-a potential pasture species Proceedings of the New Zealand Grassland Association 58: 77-86.

Stewart A, Kerr G, Lissaman W, Rowarth J 2014. Pasture and Forage plants for New Zealand. New Zealand Grassland Association. Grassland Research and Practice Series No. 8. Fourth edition. Pp. 64-65.

Watson RN, Neville FJ, Bell NL 1996a. Insect pests associated with white and Caucasian clover in a Bay of Plenty dairy pasture. New Zealand Plant Protection 49: 234-238.

Watson RN, Neville FJ, Bell NL, Harris SL 1996b. Caucasian clover as a pasture legume for dryland dairying in the coastal Bay of Plenty. Proceedings of the New Zealand Grassland Association 58: 183-188. 